Section Editor: W. A. STEINER

Note: It is the purpose of this section of the IJLL to direct the attention of readers to articles and periodical titles which may be thought to be of particular interest to them. Information concerning some of these items will be summarized, abstracted or noted at greater length and in greater detail, some more briefly and in less detail. In some cases, references only will be given. While, in general, recent articles will form the subject matter of this section, references and notations to articles previously published might be included if they are still considered useful and topical.

\title{
Comparative Law
}

-L. WELAMSON: La motivation des décisions des cours judiciaires suprémes (REVUe INTERNATIONALE DE DROIT COMPARÉ, year 31, No. 3 (July-Sept. 1979), pp. 509-519). This article is a sequel to A. TOUFFAIT and A. TUNC: Pour une motivation plus explicite des décisions de justice, notamment de celles de la Cour de Cassation (Revue TRIMESTRIELLE DE DROIT CIVIL, 1974, pp. 487 et seq.) and P. BELLET and A. TUNC: La cour judiciaire suprême: une enquête compartive (REvUE INTERNATIONALE DE DROIT COMPARÉ, 1978, pp. 3 et seq.). The author who is a judge of the Supreme Court of Sweden, discusses the functions of judgments of supreme courts and deals, in particular, with the controversial question whether there should be one judgment or individual opinions. This article is followed by J.A. JOLOWICZ: Les décisions de la Chambre des Lords (ibid., pp. 521-537). The author discusses the functions of the judgments of the House of Lords and defends the practice of having several individual opinions. This is in contrast to the view of Judge Welamson who is in favour of one judgment of the Court, accompanied by individual statements. On a related theme is G. RÁCZ: La cour suprême de Hongrie (REvUe INTERNATIONALE DE DRoIT COMPARÉ, year 31, No. 2 (April-June 1979), pp. 307-313). The author deals with the history, structure and functions of the Court, and makes the point that the Court is no longer simply a court of final appeal, but is directing the exercise of jurisdiction by other courts.

-F.A. CREPEAU: La réforme du Code civil de Québec (REvUe INTERNATIONALE DE DROIT COMPARÉ, year 31, No. 2 (April-June 1979) pp. 269- 
283). Professor Crépeau, who was in charge of the work of updating the code of 1866, describes the spirit, aims and methods of the reform. After work had been proceeding from 1962 to 1978, the completed draft was submitted to the National Assembly on the 20th of June 1978. With this may be compared the preparation of the new Dutch civil code of which an account is given by W. SNIJDERS: Vers un nouveau code civil néerlandais: état des travaux (REVUE DE DROIT INTERNATIONAL ET DE DROIT COMParÉ, year 56 (1979), pp. 223-231). From 1947, the Netherlands have been engaged in the process of replacing the civil code of 1838 with a new one. This is being done piecemeal, i.e. each Book of the new code is being enacted separately by means of its own introductory law. The article gives the present state of enactment and makes the point that this way of introducing the new code means that each Book can reflect developments in the law and in legal thought better than a code prepared in one operation by one draftsman and accepted quickly.

-M. DISTEL: La législation particulière en Grande-Bretagne et aux Etats-Unis (Revue INTERNATIONALE DE DROIT COMPARÉ, year 31, No. 2 (April-June 1979), pp. 339-380) describes the comparatively little-known institution of private and local legislation. The article discusses the functions of this type of legislation as well as the special procedure followed in its passage through Parliament and Congress. It deals with the objections to such legislation and with its importance for local administration, with its recognition of local needs and adaptation of the law to them.

-O. HANSEN: Trente années de tentatives d'unification due droit dans les pays du Benelux: une expérience (REVUE DE DROIT INTERNATIONAL ET DE DROIT COMPARÉ, year 57, No. 1 (1980), pp. 60-82). The law of each of the three partners has developed differently from similar beginnings. The Benelux customs union goes back to an agreement in London in 1944. The centre of gravity of the unification movement is to be found in economic relations. The article sets out which projects have reached the stage of coming into force, explains Parliamentary and administrative developments, and concludes with a stocktaking and with the lessons to be drawn from experience up to now.

-In the field of general comparative law, the following may be noted: J.N. HAZARD: Pourquoi le droit comparé? l'URSS et les Etats-Unis (REVUE DE DROIT INTERNATIONAL ET DE DROIT COMPARÉ, year 56 (1979), pp. 292-308). The author deals with the problems arising in the field of comparative law from the different approaches and different practice of East and West. K.H. NADELMANN : Bicentennial observations on the second edition of Joseph Story's Commentaries on the Conflict of laws (American Journal of Comparative LaW, vol. 28 No. 1 (Winter 1980), 
pp. 67-77). The first edition was published in 1834, the second one in 1841. It has remained comparatively neglected which seems unfortunate. The author analyses the changes in the second edition and discusses relations with works of other authors. It is interesting to see how much the conflicts lawyers in various countries formed a community. A. SPRUDZS : The international encyclopaedia of comparative law: a bibliographical status report (ibid., pp. 93-104). The author discusses the history and organisation of the project as well as the personnel and the bibliography of the work as published at the end of 1979 . There are bibliographical observations with suggestions for improvements. The author suggests that the bibliographies contained in the work should be published separately after editing by a professional legal bibliographer. The list of contributors is rather melancholy as it contains the names of many deceased scholars.

-H. Fix ZAMUDIO: Breve reflexiones sobre el objeto y la naturaleza de las revistas de derecho comparado (REvISTA JURÍDICA DEL PERU, year 30, No. 3 (July-Sept. 1979), pp. 187-201). A brief historical survey of the comparative law reviews, and of their functions is followed by the suggestion that there should be published an International juridical yearbook of comparative law, to be sponsored by the International Association of Legal Science, or directly by UNESCO, with the cooperation of other institutions such as the Law Department of the European University Institute in Florence/Fiesole and the Law Department of the United Nations University.

-G. CRISCUOLI: Comparazione e prospetti del diritto (DiRITto E GIURISPRUdENZA, 94, No. 4 (October-December 1979), pp. 721-728). The author discusses the contribution which comparative law can and does make to Italian legal research and development. Reflexions on comparative law are to be found in G. GORLA : Ricordi della carriera di un comparatista: da Diritto comparato al DIRITTo COMUNe EURopeo (Il foro italiano, vol. 103, part 5, No. 1 (January 1980), pp. 1-11); and G. GORLA : Prolegomena ad una storia del diritto comparato europeo (ibid., pp. 11-26). The author stresses that the history of comparative law in Europe goes back to the 12th century though these beginnings are being neglected.

- Several articles occasioned by scientific developments may be mentioned: A.E. EWING: Science, technology and development (JoURNAL OF WORLD TRADE LAw, vol. 14, No. 2 (March-April 1980), pp. 119-134). The Vienna Conference on Science and Technology for Development (UNCSTD) has shown a shift in the balance of influence from scientists to representatives of developing powers. This goes with a growing recognition of the importance of technology as compared with fundamental science for develop- 
ing countries, and the author discusses the possibility of setting up a Third World technical secretariat on the same lines as OECD and CMEA. The Revue juridique de l'environnement, 1979, No. 4 is devoted to law and solar energy. It contains the report of the proceedings of a round table conference held at Strasbourg on 21-22 June 1979 as well as relevant French legislative texts. R. CHURCHILL: Revision of the EEC's common fisheries policy-part I (EUROPEAN LAW REVIEW, vol. 5, No. 2 (February 1980), pp. 3-37). The author discusses the importance of the fisheries question within the framework of the European Communities and the need to adapt the common fisheries policy to the emergence of the exclusive economic zone. The legal issues are analysed; both internal Community relations and relations with countries and organisations outside the Communities are affected.

-G. RAHN : Reprography and copyright in Japan (INTERNATIONAL REVIEW OF INDUSTRIAL PROPERTY AND COPYRIGHT LAW, vol. 10, No. 6 (1979), pp. 710-729) is a substantial contribution to the discussion of a problem which has been of concern to IALL for many years.

- The growing interest in what may loosely be termed the legal aspects of international commercial relations is reflected in several articles and symposia. Boston College International and Comparative Law Review, vol. 2, No. 2 (1979) is devoted to a Latin American commercial law symposium. It consists of two articles on Latin America in general (Fairness in Angloand Latin-American commercial adjudication by B. KOZOLCHYK, and The effects of inflation on the law of obligations in Latin America by K.S. ROSENN) and of two articles more specially concerned with Mexico (Mexican commercial law, 1854-1884 by R.C. MEANS, and Observations on the nature of joint ventures in Mexico: are they involuntary and transitory institutions? by M.W. GORDON).

-Case Western Reserve Journal of International Law, vol. 11, No. 2 (Spring 1979) is devoted to relations with the People's Republic of China. The occasion for this special issue was the establishment of diplomatic relations between the United States and the People's Republic on 1 January 1979. The main emphasis is on trade relations. E. TAKATS: Die Neuregelung des Geschmackmusterschutzes in Ungarn (GEWERBLICHER RechtSSChutz UND URHeberRechts : INTERNATIONALER Teil. 1980. Heft 2 , pp. 92-95) is interesting as an example of an up-to-date regulation of a topic which pertains to both industrial property and copyright. It replaces legislation of 1907.

-C. KIM and C.M. LAWSON: The law of the subtle mind: the traditional Japanese conception of law (INTERNATIONAL AND COMPARATIVE 
LAW QUARTERLY, vol. 28, part 3 (July 1979), pp. 491-513). The Japanese approach in a time of social change is set against the historical and cultural background, showing the Japanese attitude towards Western law. The authors stress the absence of strict logic, dislike of litigation and the value placed on conciliation.

-C. LENOBLE: Le droit du mariage et du divorce en République Populaire de Chine (REvUE DE DROIT INTERNATIONAL ET DE DROIT COMPARÉ, year 56 (1979), pp. 7-50). A historical development of the laws, showing the rejection of feudal and bourgeois systems, is followed by a survey of actual practice in marriage and divorce.

-J. WEISMAN: Restrictions on the acquisition of land by aliens (American Journal of Comparative Law, vol. 28, No. 1 (Winter 1980), pp. 39-66). This article is based on a great deal of official information, obtained from Ministries of Justice, because of the paucity of printed sources. There are various reasons for restrictions, economic reasons, security considerations, reasons which might loosely be described as national or ethnic, reasons which might be described as those of the Common-weal. Alienage is determined according to different criteria, citizenship, residence, membership of ethnic groups; problems are caused by changes in nationality, and the authorities may have discretion in applying the law. Different considerations may apply to different types of land, e.g. public or private, urban or rural, location in a given area, value. The article finally deals with modes of acquisition, and enforcement of the restrictive legislation.

- Annales de droit: revue trimestrielle de droit belge, t. 39, No. 3-4 (1979) is devoted to the report of a study session held at Namur on 4 October 1979 by the Association des diplomés en droit de Louvain. Its subject is "La réforme de droit de la filiation", occasioned by a bill the purpose of which it is to change the Belgian law radically, viz. by abolishing the distinction between legitimate and illegitimate filiation.

-N. GAIN : La réforme du Centre national de la recherche scientifique: décret $d u 10$ Septembre 1979. The article gives a detailed exposition of the decree which reorganised the Centre and integrated it into the Ministry of the Universities. 